\title{
DOI: 10.31866/2617-2674.3.2.2020.217668
}

\section{Радислав Пересецький}

кінознавець, здобувач зі спеціальності «Кіномистецтво. Телебачення»

відділу екранно-сценічних мистецтв та культурологіі; e-mail: radislavpp@gmail.com; ORCID: 0000-0001-5656-0566 Інститут мистецтвознавства, фольклористики та етнології ім. М. Т. Рильського Національної академії наук України, Київ, Україна

\section{Рецензія на монографію \\ Володимира Наумовича Миславського «Історія українського кіно 1896-1930: факти і документи» 1 і 2 тт.}

\section{Радислав Пересецкий}

киновед, соискатель по специальности «Киноискусство. Телевидение» отдела экранно-сценических искусств и культурологии; e-mail: radislavpp@gmail.com; ORCID: 0000-0001-5656-0566 Институт искусствоведения, фольклористики и этнологии им. М. Ф. Рыльского Национальной академии наук Украины, Киев, Украина

\section{Рецензия на монографию \\ Владимира Наумовича Миславского «История украинского кино 1896-1930: факты и документы» 1 и 2 тт.}

\section{Radyslav Peresetskyi}

Film critic, PhD candidate in the speciality "Cinematographic Art, Television", Screen and Performing Arts and Cultural Studies Department; e-mail: radislavpp@gmail.com; ORCID: 0000-0001-5656-0566 Rylsky Institute of Art History, Folklore and Ethnology of the National Academy of Sciences of Ukraine, Kyiv, Ukraine

Review of Volodymyr Naumovych Myslavskyi monograph "History of Ukrainian Cinema 1896-1930: Facts and Documents" 1 and 2 vols. 

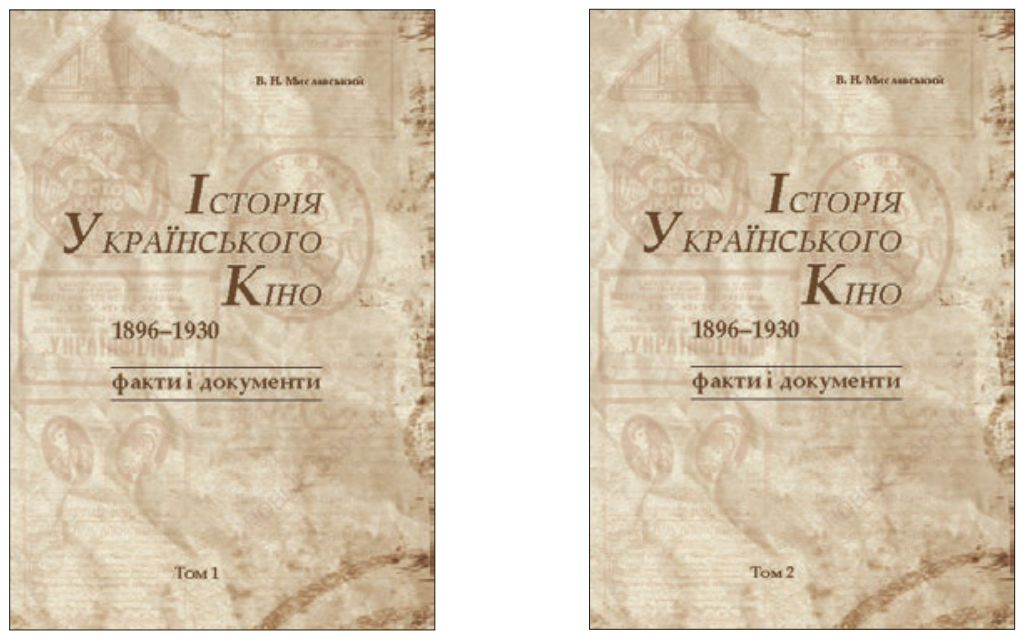

Миславський В. Н. Історія українського кіно 1896-1930: факти і документи. Харків : Дім Реклами, 2018. Т. 1. 680 с. : 506 іл.

Миславський В. Н. Історія українського кіно 1896-1930: факти і документи. Харків : Дім Реклами, 2018. Т. 2. 528 с. : 827 іл.

Двотомне монографічне видання «ICторія українського кіно 1896-1930: факти і документи» відомого українського кінознавця, доктора мистецтвознавства Володимира Миславського репрезентує у широкому соціокультурному контексті феномен виникнення та історію розвитку української кінематографії німого періоду (1896-1930). Пропонована увазі читача праця докладно відтворює цікаву в усіх відношеннях епоху українського кіно, а разом із нею - і значну частину й досі маловідомої історії української культури.

Джерельною базою фундаментального дослідження стали матеріали вітчизняних та іноземних архівів, приватні колекції, мемуари, тогочасна газетна та журнальна періодика та багато інших історичних артефактів. Загалом кількість опрацьованого сягає понад три з половиною тисячі першоджерел, переважно документальних свідоцтв того часу. Не менш вражає обсяг текстового (1208 сторінок) та іконографічного матеріалів (1333 ілюстрації - кінокадри, фотографії, картки акторів і кінодіячів, кінопостери й інше). При цьому, значна частина цієї безцінної культурної спадщини оприлюднена вперше.

Наголошена вище інформаційна насиченість зумовлена 30-річним досвідом науковця, у авторському доробку якого вже понад 40 видань з української кіноісторії, серед яких перші у світі книжки про піонерів українського кіно - кінови- 
нахідника Йосипа Тимченка, першого українського кінооператора Альфреда Федецького, кінопідприємця Дмитра Харитонова, біофільмографічні довідники з раннього періоду історії кіно в Україні. Тож у пропонованій роботі В. Миславський акумулював свої численні надбання та попередні напрацювання. Особливо зазначимо, що за обсягом наданого матеріалу ця енциклопедична праця не має аналогів серед україномовних кіноісторичних видань за усі часи незалежної України.

Структурно двотомне видання поділяється на шість розділів. Два перші розглядають зародження і становлення українського кінематографа у дореволюційну добу (1896-1916) та кінематограф на теренах України у період революцій та громадянської війни (1917-1921). Останні чотири розділи зосереджені на висвітленні широкого спектра процесів у період діяльності ВУФКУ (Всеукраїнського фотокіноуправління, 1922-1930), організації, яка забезпечила стійкий і поступальний розвиток українського кіно в умовах нової економічної політики. При цьому окрім соціально-економічних та політичних умов становлення української кінематографії розглянуто художні, тематичні та жанрові пошуки майстрів національного кіно, а також тенденції та пріоритети репертуарної політики в Україні в 1920-ті роки. Саме про це шостий розділ, до речі, найбільший за обсягом - понад 420(!) сторінок, що має певні підстави.

Показово, що увага багатьох сучасних дослідників української кіноісторії сфокусована головним чином на найуспішнішому, з точки зору художніх і економічних здобутків, етапі українського кіно другій половині 1920-х років, коли національне кіномистецтво досягло розквіту і набуло всесвітнього визнання. Про цю тенденцію свідчить не лише розглядувана праця В. Миславського, але й кінознавчі розвідки, які здійснили впродовж останніх років провідні представники української кіноісторіографії О. Безручко, Л. Брюховецька, О. Мусієнко, Р. Росляк, В. Скуратівський, С. Тримбач, науковці Києво-Могилянської Академії, Інституту мистецтвознавства, фольклористики та етнології ім. М. Т. Рильського НАН України, Київського національного університету театру, кіно і телебачення імені І. К. Карпенка-Карого, співробітники Національного центру Олександра Довженка.

До наукового обігу та культурологічного дискурсу все частіше залучаються картини як давно визнаних корифеїв українського кіномистецтва - О. Довженка, Дзиґи Вертова, І. Кавалерідзе, Г. Стабового, Г. Тасіна, так і фільми М. Шпиковського, М. Кауфмана, П. Чардиніна, А. Кордюма, А. Лундіна, Г. ГричерЧериковера, Ф. Лопатинського, Л. Могилевського та багатьох інших режисерів, які плідно працювали в 1920-ті роки. 3 року в рік також постійно зростає увага дослідників до кінокритичної та теоретичної спадщини діячів тогочасної української кінематографії - Л. Скрипника, М. Бажана, В. Хмурого, Я. Савченка, О. Вознесенського, О. Перегуди, М. Борисова-Володимирова, наробки яких упродовж багатьох десятиліть залишалися на марґінесах кінознавчої наукової думки.

Повернення історичної пам'яті - кропіткий поступовий процес. 3 цього приводу дослідницька робота В. Миславського дещо схожа на археологію кіно, спроби відродження колись загубленої кінематографічної Атлантиди, яка все більше постає з напівзабуття і вже не $є$ таємничою terra incognita. 
У епіграфі до своєї праці автор декларує, що концепції приходять і тануть, а факти залишаються. Така заявлена фактографічна настанова дійсно має певну рацію. Так само як і попередні, представлена академічна робота В. Миславського, особливо її аналітичнофактографічна складова, проторовує шлях для діючих та майбутніх дослідників українського кінематографічного ландшафту розглядуваного періоду. Од- нак суттєвим недоліком, як для наукового видання, $є$ відсутність зведеного переліку використаних джерел та бібліографії, а також іменного та фільмового покажчиків, що значно ускладнює пошук для роботи з необхідними матеріалами. Втім, пропонована фундаментальна праця В. Миславського без сумніву стала корисним та довгоочікуваним науковим дослідженням з історії української кінематографії. 